\title{
OCENA SKUTECZNOŚCI OPIEKI OTRZYMYWANEJ OD PIELEGGNIAREK I NIEPROFESJONALNYCH OPIEKUNÓW DOKONANA PRZEZ CHORYCH NA REUMATOIDALNE ZAPALENIE STAWÓW
}

\section{EFFECTIVENESS OF CARE RECEIVED FROM NURSES AND NON-PROFESSIONAL CAREGIVERS EVALUATED BY PATIENTS WITH RHEUMATOID ARTHRITIS}

\author{
Magdalena Staszkiewicz ${ }^{1}$, Anna Nawalana ${ }^{1}$, Aldona Wróbel ${ }^{1}$, Anna Majda $^{2}$ \\ ${ }^{1}$ studentka studiów doktoranckich na Wydziale Nauk o Zdrowiu \\ Uniwersytet Jagielloński - Collegium Medicum w Krakowie \\ ${ }^{2}$ Pracownia Teorii i Podstaw Pielęgniarstwa \\ Uniwersytet Jagielloński - Collegium Medicum w Krakowie
}

DOI: https://doi.org/10.20883/pielpol.2017.3

\begin{abstract}
STRESZCZENIE
Wstęp. Choroby reumatyczne przebiegają z epizodami remisji i zaostrzeń. W każdym z tych okresów chorzy muszą przystosowywać się do ograniczeń, jakie powstają w wyniku choroby, oraz przeorganizować swoje życie, często jednocześnie uzależniając się od osób drugich. Wysoki poziom sprawowanej i otrzymywanej opieki może pozytywnie wpływać na jakość życia chorych na reumatoidalne zapalenie stawów (RZS).

Cel. Celem pracy była ocena skuteczności otrzymywanej opieki od pielęgniarek i opiekunów nieprofesjonalnych oraz jej wpływu na wybrane obszary życia chorych na RZS.

Materiał i metody. Badania przeprowadzono w $2015 \mathrm{r}$. na terenie oddziału reumatologicznego w Małopolsce. W badaniach uczestniczyło 40 chorych na RZS. W badaniu wykorzystano autorskie narzędzie badawcze-Skalę Skuteczności Otrzymywanej Opieki (SSOop), którą poddano procesowi standaryzacji. Drugim narzędziem był Kwestionariusz Nottingham Health Profile (NHP).

Wyniki. Poziom skuteczności otrzymywanej opieki od pielegniarek i opiekunów nieprofesjonalnych w opinii chorych na RZS był głównie na poziomie wysokim oraz umiarkowanym i nie różnił się. Jednakże wysoki poziom otrzymywanej opieki od opiekunów korelował z wysoką jakością życia chorych na RZS w skalach: reakcje emocjonalne oraz wyobcowanie społeczne $(p<0,01)$.

Wnioski. Wysoki poziom skuteczności otrzymywanej opieki od opiekunów nieprofesjonalnych warunkował wysoką jakość życia chorych na RZS w obszarze psychospołecznym.
\end{abstract}

SŁOWA KLUCZOWE: reumatoidalne zapalenie stawów, jakość życia, opieka.

\section{Wstęp}

Reumatoidalne zapalenie stawów (RZS) jest chorobą układową tkanki łącznej o podłożu autoimmunologicznym [1, 2].

Kobiety chorują trzy razy częściej niż mężczyźni. Szczyt zapadalności przypada na 4. i 5. dekadę życia. Po 2 latach u chorego z nieleczonym RZS dochodzi do

\begin{abstract}
Introduction. Rheumatic diseases have episodes of remission and exacerbation. In each of these periods, patients must adapt to the limits caused by disease and reorganize their lives. It often leads to being dependent on other persons. High levels of performed and received care can positively affect the quality of life of patients with rheumatoid arthritis (RA).

Aim. The aim of this study was to assess the effectiveness of care received from nurses and non-professional caregivers and its impact on selected areas of life of patients with RA.

Material and methods. The study was conducted in 2015 in the Department of Rheumatology in Malopolska. The study involved 40 patients with RA. In the study authors used their own research tool - Efficacy Scale of Received Care, which had undergone a process of standardization. The second tool was a questionnaire - Nottingham Health Profile (NHP).

Results. The level of effectiveness of the care received from nurses and non-professional caregivers in the opinion of RA patients was mainly at the level of high and moderate and did not differ. However, the high level of care received from caregivers correlated with the quality of life of patients with RA in reference to: emotional reactions and social alienation $(p<0.01)$.

Conclusions. The high level of effectiveness of care received from non-professional caregivers conditioned the quality of life of the patients with rheumatoid arthritis in the psychosocial.
\end{abstract}

KEYWORDS: rheumatoid arthritis, quality of life, care.

znacznej destrukcji stawów [2]. Charakterystyczne objawy stawowe u pacjenta z RZS to m.in. symetryczny ból i obrzęk stawów rąk i stóp oraz sztywność poranna [3]. Często objawom stawowym w RZS towarzyszą stany podgorączkowe, bóle mięśni, utrata masy ciała i przewlekłe zmęczenie $[4,5]$. 
W 2012 r. Narodowy Instytut Zdrowia Publicznego oszacował, że w Polsce na poważne dolegliwości reumatyczne, które mogą stać się przyczyną inwalidztwa (w tym również RZS), cierpi 10\% mężczyzn i $25 \%$ kobiet między 30. a 60. rokiem życia [6]. Co najmniej 12,1\% przypadków absencji chorobowej związanych jest z chorobami reumatycznymi [7].

„Jakość życia” to termin, który przyjął się na Zachodzie Europy w połowie ubiegłego stulecia. Najpierw miał on znaczenie czysto materialne, później poszerzono jego zakres do aspektów poczucia szczęścia, bycia zdrowym, posiadania wykształcenia i zdolności do rozwoju [8, 9].

RZS jest chorobą, która w dużej mierze decyduje o jakości życia chorych [10]. Bardzo często zmagają się oni z takimi trudnościami, jak: ból, ograniczenie zakresu ruchów, zmęczenie, depresja, inwalidztwo. Niepełnosprawność, której doświadczają, ma duży wpływ na stan zdrowia psychicznego. Powoduje ona wycofanie się chorego z pełnienia ról społecznych, z codziennej aktywności życiowej, co znacznie utrudnia proces leczniczy [11, 12]. Jakość życia jest niewątpliwie ważnym czynnikiem warunkującym efektywność leczenia chorego. W RZS zapewnienie dobrej jakości życia, powrót do stanu sprzed choroby to jedne z głównych celów terapii. Dwunastego października każdego roku obchodzimy Światowy Dzień Reumatyzmu, którego głównymi hasłami są: jakość życia i niezależność [9].

Chorzy na RZS często w przebiegu choroby tracą zdolność do samodzielnego funkcjonowania. Powoduje to obniżenie ich nastroju oraz poczucia własnej skuteczności. Niezwykle ważna jest wtedy rola opiekuna nieprofesjonalnego i pielęgniarki - osób pielęgnujących chorego, przyczyniających się do poprawy komfortu jego życia, a wielokrotnie także stanu psychicznego.

Celem pracy była ocena skuteczności otrzymywanej opieki od opiekunów nieprofesjonalnych i pielęgniarek oraz jej wpływu na wybrane obszary życia chorych na RZS.

\section{Materiał i metody}

Badania zostały podzielone na trzy części. W pierwszej części scharakteryzowano ból jako czynnik warunkujący jakość życia chorych na RZS i ich funkcjonowanie w życiu codziennym. Druga część badań dotyczy poziomu skuteczności sprawowanej opieki nad pacjentami z RZS przez pielęgniarki i opiekunów nieprofesjonalnych. Ostatnia część prezentuje opinię chorych na RZS dotyczącą opieki otrzymywanej od opiekunów nieprofesjonalnych i pielęgniarek; w tej części chorzy mówią też o jakości swego życia. Niniejsze badanie jest badaniem wstępnym (pilotażowym), które zostało wykorzystane do opracowania autorskich narzędzi badawczych, które zostały poddane procesowi standaryzacji.
Jako opiekunów nieprofesjonalnych chorzy na RZS wymieniali osoby towarzyszące im w życiu codziennym, które pomagają pokonywać ograniczenia wynikające $\mathrm{z}$ choroby (np.: współmałżonek, dziecko, sąsiad).

Pacjenci z RZS w narzędziu autorskim oceniali skuteczność opieki pielęgniarek pracujących w oddziale reumatologicznym. Ocenie podlegały postawa pielęgniarek oraz ich interwencje opiekuńcze i pielęgnacyjne podejmowane podczas hospitalizacji na rzecz osób z RZS.

Badania prowadzano od listopada do grudnia 2015 r. w oddziale reumatologicznym w Małopolsce, w którym byli diagnozowani i leczeni chorzy na reumatoidalne zapalenie stawów. Grupę badaną stanowiło 40 chorych na RZS. Najiczniejszą grupę stanowiły osoby z wykształceniem zawodowym, będące na emeryturze oraz chorujące od około 6-10 lat (Tabela 1).

Tabela 1. Charakterystyka pacjentów z RZS $(n=40)$ Table 1. Characteristics of the patients with $R A(n=40)$

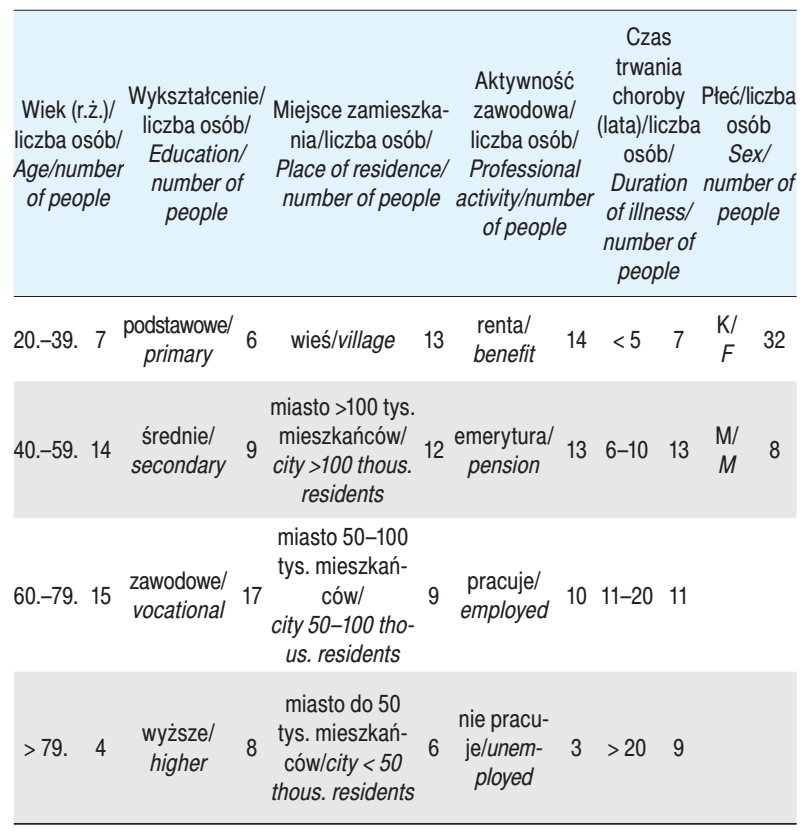

$\mathrm{n}$ - liczba badanych osób/number of persons surveyed

Źródło: opracowanie własne

Source: author's own analysis

W badaniu wykorzystano metodę szacowania oraz metody statystyczne, które pozwoliły na wnikliwą analizę zebranego materiału badawczego [13]. Zastosowano autorskie narzędzie badawcze - Skalę Skuteczności Otrzymywanej Opieki (SSOop). Opracowana skala składała się z dwóch części, które liczyły po 10 pytań. Pierwsza z nich dotyczyła opieki otrzymywanej od osób bliskich (opiekunów nieprofesjonalnych). Druga część odnosiła się do opieki sprawowanej przez pielęgniarki. Respondent w każdej z części udzielał od- 
powiedzi, zaznaczając wariant: „Zdecydowanie tak” (5 pkt.), „Raczej tak” (4 pkt.), „Nie wiem” (3 pkt), „Raczej nie” (2 pkt.) oraz „Zdecydowanie nie” (1 pkt.). Zarówno w części pierwszej, jak i drugiej badany mógł uzyskać od 10 do 50 punktów. Na podstawie analizy statystycznej ustalono zakresy norm punktowych (osobno dla pielęgniarek, osobno dla opiekunów), które warunkowały podział skuteczności otrzymywanej opieki na: niską (10-34 pkt.), umiarkowaną (35-43 pkt.) oraz wysoką (44-50 pkt.) - opiekunowie nieprofesjonalni, oraz: niską (10-35 pkt.), umiarkowaną (36-40 pkt.) i wysoką (41-50 pkt.) - pielęgniarki.

Dla pierwszej części kwestionariusza (odnoszącej się do opiekunów) współczynnik $\alpha$-Cronbacha wyniósł 0,955, dla drugiej (dotyczącej pielęgniarek) - 0,916. Potwierdziło to rzetelność opracowanego narzędzia, które zastosowano w niniejszym badaniu.

Drugim narzędziem wykorzystanym w badaniu był Nottingham Health Profile (NHP) autorstwa Hunt, McEwan, McKenna (polska adaptacja wykonana przez Bojarską, Pikułę oraz Wrześniewskiego) [8]. Kwestionariusz NHP zawierał listę problemów pojawiających się w codziennym życiu, które przedstawione zostały w postaci 38 twierdzeń, np.: „Trudno mi nawiązać kontakt z ludźmi”, „Wszystko robię z wysiłkiem”, „Szybko tracę siły". Respondent musiał się do nich ustosunkować, zaznaczając wariant: „Tak” lub „Nie”. Wszystkie twierdzenia wchodziły w skład 6 skal: energia, ból, reakcje emocjonalne, zaburzenia snu, wyobcowanie społeczne, ograniczenia ruchowe. Badały one różne obszary jakości życia pacjentów z RZS (np.: obszar funkcjonowania psychospołecznego, obszar funkcjonowania fizycznego). Z niniejszej analizy wyłączono 8 twierdzeń dotyczących skali: ból, gdyż staną się przedmiotem rozważań w innej publikacji.

Wynik surowy uzyskano dla każdej z 5 skal poprzez zsumowanie odpowiedzi „Tak” - im wyższy wynik, tym większe upośledzenie danego obszaru funkcjonowania, co oznaczało gorszą ogólną jakość życia. Na podstawie wykonanych analiz postanowiono umownie podzielić poziomy jakości życia na: wysoki, umiarkowany oraz niski dla każdej z 5 skal Kwestionariusza NHP. Wysoki poziom jakości życia wyłoniono na podstawie uzyskania 0-33,33\% udzielonych odpowiedzi twierdzących, umiarkowany: 33,34-66,66\% odpowiedzi twierdzących, oraz niski: 66,64-100\% odpowiedzi „Tak”.

Związek między poszczególnymi zmiennymi sprawdzono przy użyciu metod statystyki opisowej, testu chi-kwadrat oraz testu korelacji rang Spearmana, przyjmując poziom istotności dla $\mathrm{p}<0,05$.

\section{Wyniki badań}

Chorzy na reumatoidalne zapalenie stawów pozytywnie oceniali poziom sprawowanej opieki przez opiekunów. Najczęściej był on określany jako umiarkowany (15 osób). Niewiele mniej respondentów oceniło go jako wysoki (13 osób) i najmniej badanych - jako niski (12 osób). Poziom otrzymywanej opieki od pielęgniarek najczęściej był określany na poziomie umiarkowanym (17 osób) oraz wysokim (14 osób). Uśredniony wynik dla opiekunów i pielęgniarek to odpowiednio: $M=39,0$; $\mathrm{M}=38,7$ (SD: 9,1; 6,0) (Tabela 2).

Tabela 2. Opinia chorych na RZS dotycząca skuteczności opieki otrzymywanej od opiekunów nieprofesjonalnych i pielęgniarek $(n=40)$ Table 2. Opinion of RA patients on the effectiveness of care received from non-professional caregivers and nurses $(n=40)$

\begin{tabular}{|c|c|c|c|c|c|c|c|c|}
\hline \multirow[t]{2}{*}{$\begin{array}{l}\text { Uczestnicy badania/ } \\
\text { The study participants }\end{array}$} & \multirow[t]{2}{*}{ s M } & \multirow[t]{2}{*}{$\mathrm{SD}$} & \multirow[t]{2}{*}{$\mathrm{Me}$} & \multirow[t]{2}{*}{ Mo } & \multirow[t]{2}{*}{ Q1 Q3 } & \multicolumn{3}{|c|}{$\begin{array}{l}\text { Poziom skuteczności } \\
\text { otrzymywanej opieki } \\
\text { (SSOop } 1 \mathrm{~A} \text { i 1B)/ } \\
\text { The level of received } \\
\text { care effectiveness }\end{array}$} \\
\hline & & & & & & $\begin{array}{r}\text { niski/ } \\
\text { low }\end{array}$ & $\begin{array}{l}\text { prze- } \\
\text { ciętny/ } \\
\text { average }\end{array}$ & $\begin{array}{l}\text { wyso- } \\
\mathrm{ki} / \\
\mathrm{high}\end{array}$ \\
\hline $\begin{array}{l}\text { Opinia dotycząca } \\
\text { opiekunów/ } \\
\text { Opinion on carers }\end{array}$ & 39,0 & 9,1 & 40,5 & 50 & 3248 & 12 & 15 & 13 \\
\hline $\begin{array}{l}\text { Opinia dotycząca } \\
\text { pieleggniarek/ } \\
\text { Opinion on nurses }\end{array}$ & 38,7 & 6 & 39,5 & $\begin{array}{l}\text { wielo- } \\
\text { krotna/ } \\
\text { multiple }\end{array}$ & 3642 & 9 & 17 & 14 \\
\hline
\end{tabular}

M - średnia/average; SD - odchylenie standardowe/standard deviation; Me - mediana/median; Mo - moda/mode; Q1 - kwartyl dolny/lower quintile; Q3 - kwartyl górny/upper quantile; $\mathrm{n}$ - liczba badanych osób/number of persons surveyed

Źródło: opracowanie własne

Source: author's own analysis

Wyniki otrzymywanej opieki od opiekunów i pielęgniarek (na podstawie autorskiej Skali SSOop) szczegółowo zaprezentowano w tabeli 3. Najczęściej chorzy na RZS w pytaniach dotyczących ich zadowolenia z opieki sprawowanej przez opiekunów nieprofesjonalnych i pielęgniarki udzielali odpowiedzi „Zdecydowanie tak” oraz „Raczej tak”. Większość badanych (32 osoby) stwierdziła, iż jakość ich życia ulega poprawie dzięki pomocy udzielanej od opiekuna i pielęgniarki. Trzydziestu trzech respondentów stwierdziło, iż otrzymuje pomoc od opiekuna w rozwiązywaniu problemów wynikających z ograniczeń uwarunkowanych chorobą. Pomoc od pielęgniarki deklarowało 34 badanych (Tabela 3). 
Tabela 3. Autorskie narzędzie badawcze: Skala Skuteczności Otrzymywanej Opieki - odpowiedzi badanych $(n=40)$

Table 3. Proprietary research tool: Efficacy Scale of Received Care the respondents' answers $(n=40)$

\begin{tabular}{|c|c|c|c|c|c|c|c|c|c|c|}
\hline \multirow{3}{*}{$\begin{array}{l}\text { Stwierdzenie/ } \\
\text { Statement }\end{array}$} & \multicolumn{10}{|c|}{ Wariant odpowiedzi/Answer } \\
\hline & \multicolumn{2}{|c|}{ A } & \multicolumn{2}{|c|}{$\mathrm{B}$} & \multicolumn{2}{|c|}{ C } & \multicolumn{2}{|c|}{$\mathrm{D}$} & \multicolumn{2}{|c|}{$E$} \\
\hline & 0 & $\mathrm{p}$ & 0 & $p$ & 0 & $\mathrm{p}$ & 0 & $\mathrm{p}$ & 0 & $p$ \\
\hline $\begin{array}{l}\text { 1. Jakość mojego życia ulega } \\
\text { poprawie dzięki udzielanej } \\
\text { pomocy od:/ } \\
\text { My quality of life has been } \\
\text { improving thanks to care } \\
\text { given by: }\end{array}$ & 16 & 8 & 16 & 24 & 6 & 7 & 2 & 1 & 0 & 0 \\
\hline $\begin{array}{l}\text { 2. Jestem w pełni usatysfak- } \\
\text { cjonowany z opieki niesionej } \\
\text { przez:// am fully satisfied with } \\
\text { care carried by: }\end{array}$ & 14 & 7 & 17 & 20 & 4 & 5 & 5 & 8 & 0 & 0 \\
\hline $\begin{array}{l}\text { 3. Wiem, że zawsze moge } \\
\text { liczyć na pomoc:/l know that } \\
\text { I can always count on: }\end{array}$ & 15 & 9 & 15 & 26 & 4 & 5 & 6 & 0 & 0 & 0 \\
\hline $\begin{array}{l}\text { 4. Bez oporów proszę } \\
\text { o pomoc:/l can ask for help } \\
\text { without hesitation: }\end{array}$ & 15 & 9 & 15 & 25 & 3 & 5 & 7 & 0 & 0 & 0 \\
\hline $\begin{array}{l}\text { 5. Czuję się bezpiecznie dzię- } \\
\text { ki opiece, którą otrzymuję } \\
\text { od:/l feel safe thanks to care } \\
\text { I receive from: }\end{array}$ & 15 & 13 & 14 & 21 & 4 & 5 & 7 & 1 & 0 & 0 \\
\hline 6. Mam zaufanie do:// trust: & 16 & 4 & 15 & 21 & 2 & 8 & 7 & 6 & 0 & 1 \\
\hline $\begin{array}{l}\text { 7. Myślę, że osoba sprawu- } \\
\text { jąca nade mną opiekę ma } \\
\text { odpowiedni poziom wiedzy/ } \\
\text { I think that the person who } \\
\text { has been taking care of me } \\
\text { has an appropriate level of } \\
\text { knowledge }\end{array}$ & 11 & 5 & 13 & 21 & 2 & 6 & 7 & 8 & 2 & 0 \\
\hline $\begin{array}{l}\text { 8. Jestem rozumiany przez:/ } \\
\text { I am understood bv: }\end{array}$ & 14 & 2 & 16 & 28 & 3 & 4 & 6 & 6 & 1 & 0 \\
\hline $\begin{array}{l}\text { 9. Uważam, że: ... rozpoznaje } \\
\text { moje potrzeby/l think that ... } \\
\text { recognizes my needs }\end{array}$ & 11 & 3 & 14 & 27 & 4 & 3 & 11 & 7 & 0 & 0 \\
\hline $\begin{array}{l}\text { 10. ... pomaga mi w rozwią- } \\
\text { zaniu problemów wynikają- } \\
\text { cych z ograniczeń spowodo- } \\
\text { wanych chorobą/ } \\
\text {... helps me solve problems } \\
\text { arising from limitations } \\
\text { caused by illness }\end{array}$ & 11 & 10 & 22 & 24 & 1 & 5 & 5 & 1 & 1 & 0 \\
\hline $\begin{array}{l}\text { 11. Jestem zależny/-a od/ } \\
\text { I am dependent on ... }\end{array}$ & 0 & 2 & 2 & 4 & 2 & 4 & 29 & 20 & 7 & 10 \\
\hline $\begin{array}{l}\text { 12. Jestem obciążeniem dla ... / } \\
\text { I am a burden to ... }\end{array}$ & 0 & 0 & 2 & 0 & 4 & 6 & 25 & 19 & 9 & 15 \\
\hline
\end{tabular}

o - opiekun/caregiver, $\mathrm{p}$ - pielęgniarka/nurse;

A - Zdecydowanie tak/Absolutely yes; B - Raczej tak/Rather yes; C - Nie wiem/ I do not know; D - Raczej nie/Not really; E - Zdecydowanie nie/Definitely not

Źródło: opracowanie własne

Source: author's own analysis

Analiza Kwestionariusza NHP pozwoliła określić jakość życia chorych na RZS. Respondenci najczęściej wskazywali niską jakość życia w twierdzeniach zawartych w skalach: energia i zaburzenia snu. Połowa pacjentów określiła, że poziom ich funkcjonowania odnoszący się do skali: energia był niski, a 13 osób stwierdziło, iż był on umiarkowany. Na niską jakość snu w twierdzeniach dotyczących skali: zaburzenia snu skarżyło się 20 osób; 12 respondentów uważało, że zaburzenia te były umiarkowane. Wśród chorych 9 badanych skarżyło się na ograniczenia ruchowe i poruszania się oraz 14 osób na umiarkowany brak ruchomości. Przeciwne wyniki przedstawiają się w skalach: reakcje emocjonalne i wyobcowanie społeczne. Ponad połowa chorych (23 osoby) twierdziła, iż jakość ich życia w skali: reakcje emocjonalne była wysoka, 10 osób uważało, iż była umiarkowana. Wyobcowanie społeczne również nie dotyczyło większości chorych. Spośród respondentów 20 osób podawało, że czują się bardzo dobrze w kontaktach z innymi i nie czują się wyobcowani. O umiarkowanej jakości życia w skali: wyobcowanie społeczne mówiło 13 osób (Tabela 4).

Tabela 4. Związek między skutecznością otrzymywanej opieki od opiekunów i pielęgniarek a jakością życia warunkowaną dziedzinami Kwestionariusza NHP $(n=40)$

Table 4. The relationship between the effectiveness of the care received from caregivers and nurses and the quality of life according to fields of the NHP Questionnaire $(n=40)$

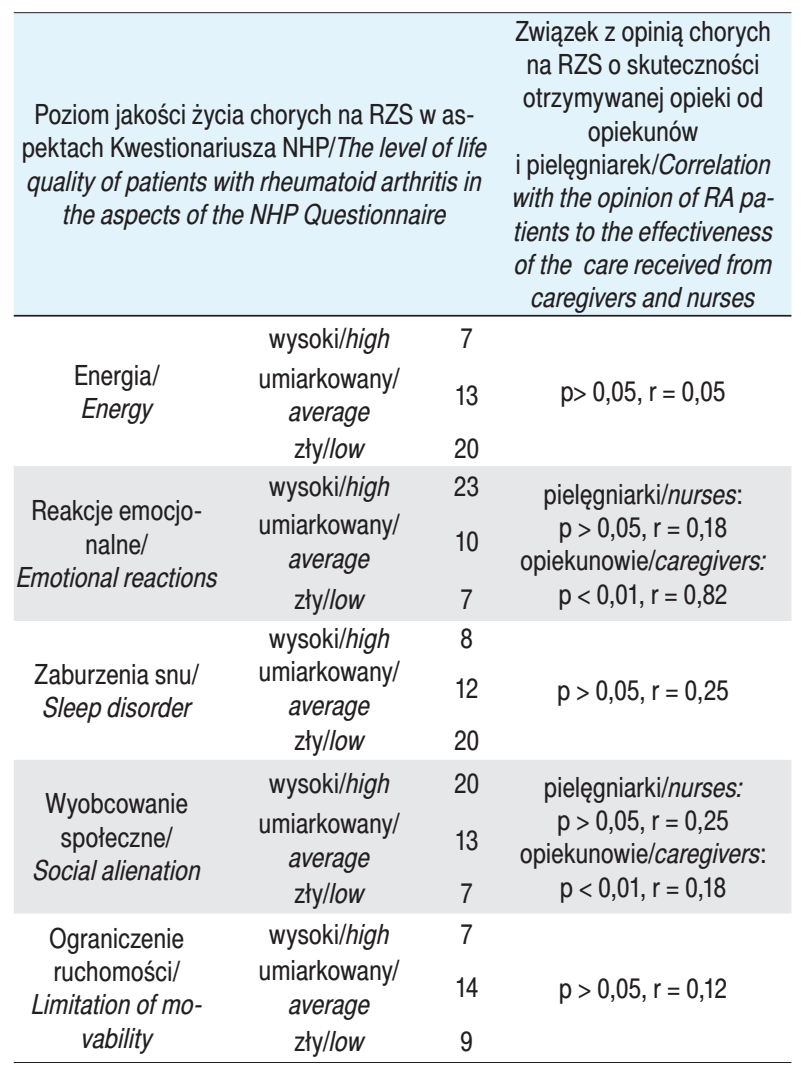

Źródło: opracowanie własne

Source: author's own analysis

Na podstawie uzyskanych wyników zbadano związek między jakością życia chorych na RZS, uwzględniając skale Kwestionariusza NHP, a poziomem otrzymywanej 
opieki od opiekunów nieprofesjonalnych i pielęgniarek. Wykazano, że wysoki poziom opieki otrzymywanej od opiekunów miał decydujący wpływ na wyniki 2 skal: reakcje emocjonalne i wyobcowanie społeczne $(p<0,01)$ (Tabela 4). Chorzy, którzy zadeklarowali wysoki poziom otrzymywanej opieki od opiekunów, określili istotnie wyższy poziom jakości życia w 2 wyżej wymienionych skalach: reakcje emocjonalne i wyobcowanie społeczne $(p<0,01)$. Nie wykazano związku między otrzymywaną opieką od opiekunów a skalami: energia, ograniczenia ruchowe i zaburzenia snu $(p>0,05)$.

Wyłoniono związki $(p<0,05)$ oraz silne związki $(p<0,01)$ między wysokim poziomem otrzymywanej opieki od opiekunów a wybranymi stwierdzeniami z Kwestionariusza NHP. Większość stwierdzeń zawarta była w skalach: reakcje emocjonalne i wyobcowanie społeczne (Tabela 5).

Tabela 5. Związek między wybranymi twierdzeniami z Kwestionariusza NHP a wysokim poziomem otrzymywanej opieki od opiekunów i pielęgniarek

Table 5. Association of selected statements of the NHP Questionnaire with the high level of care received from caregivers and nurses

\begin{tabular}{|c|c|}
\hline $\begin{array}{l}\text { Istotne stwierdzenia Kwestionariusza NHP/ } \\
\text { Relevant statements from the NHP } \\
\text { Questionnaire }\end{array}$ & $\begin{array}{l}\text { Związek z opinią chorych na } \\
\text { RZS o skuteczności otrzymywa- } \\
\text { nej opieki od opiekunów/Rela- } \\
\text { tionship with the opinion of RA } \\
\text { patients about the effectiveness } \\
\text { of care received from caregivers }\end{array}$ \\
\hline $\begin{array}{l}\text { Wszystko mnie przygnębia/ } \\
\text { Everything depresses me }\end{array}$ & $p<0,05, r=0,67$ \\
\hline Jestem rozdrażniony/l am irritated & $p<0,05, r=0,16$ \\
\hline Czuję się osamotniony/l feel lonely & $\mathrm{p}<0,01, \mathrm{r}=0,11$ \\
\hline $\begin{array}{c}\text { Czas mi się dłuży/l feel that the time } \\
\text { drags on }\end{array}$ & $p<0,01, r=0,14$ \\
\hline $\begin{array}{l}\text { Czuje, że nie mam nikogo bliskiego// feel } \\
\text { that / do not have anyone close to me }\end{array}$ & $\mathrm{p}<0,01, \mathrm{r}=0,01$ \\
\hline $\begin{array}{l}\text { Ostatnio łatwo wpadam w złośćl } \\
\text { l've become irritable recently }\end{array}$ & $\mathrm{p}<0,01, \mathrm{r}=0,75$ \\
\hline $\begin{array}{l}\text { Nie moge długo zasnąć w nocy/ } \\
\text { I cannot fall asleep at night }\end{array}$ & $p<0,05, r=0,33$ \\
\hline $\begin{array}{l}\text { Czuje, że jestem dla innych ciężarem// feel } \\
\text { that I am a burden to others }\end{array}$ & $p<0,05, r=0,07$ \\
\hline \multirow[t]{2}{*}{$\begin{array}{c}\text { Czuje, że nie warto żyć/l feel that it is not } \\
\text { worth living }\end{array}$} & $p<0,01, r=0,11$ \\
\hline & $\begin{array}{l}\text { Związek z opinią chorych na } \\
\text { RZS o skuteczności otrzymywa- } \\
\text { nej opieki od pielegniarek/Rela- } \\
\text { tionship with the opinion of RA } \\
\text { patients about the effectiveness } \\
\text { of care received from nurses }\end{array}$ \\
\hline Jestem stale zmęczony// am constantly tired & $p<0,05, r=0,18$ \\
\hline
\end{tabular}

Źródło: opracowanie własne

Source: author's own analysis

Wysoki poziom otrzymywanej opieki od opiekunów miał pozytywny wpływ na sytuacje przedstawione w postaci stwierdzeń w tabeli, które określały te skale.
Nie wykazano związków między otrzymywaną opieką od pielęgniarek a skalami Kwestionariusza NHP oraz nie wykazano związku między umiarkowanym i wysokim poziomem otrzymywanej opieki od pielęgniarek a jakością życia chorych na RZS.

\section{Dyskusja}

Reumatoidalne zapalenie stawów ma negatywny wpływ na jakość życia chorych, która obniża się wraz z postępem schorzenia [14, 15]. Jedno z międzynarodowych badań wykazało, że aż 95\% polskich pacjentów cierpiących na RZS czuje się wykluczonych z życia społecznego. Podobne odczucia miało 62\% pacjentów niemieckich [16]. Inne badania wykazały, że w Polsce zaledwie 38\% osób z RZS jest zadowolonych z życia. Przed pojawieniem się objawów choroby zatrudnionych było około $62 \%$ ankietowanych, jednak wielu z nich krótko po postawieniu diagnozy musiało zrezygnować z pracy $[17,18]$.

Badania własne zaprezentowały jakość życia chorych na RZS z uwzględnieniem 5 skal, takich jak: energia, rekcje emocjonalne, zaburzenia snu, wyobcowanie społeczne i ograniczenie ruchomości. W skali: ograniczenie ruchomości respondenci głównie odpowiadali, że ich jakość życia była niska. Wynikać to mogło przede wszystkim z ich stanu zdrowia, bowiem w okresie zaostrzenia choroby (pacjenci oddziału szpitalnego) dochodzi najczęściej do pogłębienia niepełnosprawności i ograniczeń funkcjonowania w życiu codziennym [19]. Odmienne wyniki badań dotyczyły dwóch skal: reakcje emocjonalne i wyobcowanie społeczne. Jakość życia badanych określona tymi skalami była głównie wysoka, z uwagi na wysoki poziom sprawowanej opieki przez opiekunów nieprofesjonalnych. Opiekunowie, zapewniając wysoki poziom opieki nad chorymi (jak wskazują wyniki w obszarze funkcjonowania psychospołecznego), mogą dać im poczucie bezpieczeństwa, oddalić od stanów przygnębienia, gniewu, rozdrażnienia i osamotnienia. Chorzy czują się wartościowymi ludźmi. Mają świadomość, że innym na nich zależy. Sprawia to, że ich poczucie wartości wzrasta. Dzięki temu chorzy chętniej uczestniczą w życiu społecznym i są mniej narażeni na wystąpienie stanów depresyjnych [20]. Badania innych autorów również wskazują na niską jakość życia chorych na RZS w obszarze funkcjonowania fizycznego - w skalach takich jak: energia oraz zaburzenia snu i ograniczenia ruchowe [21]. Można przypuszczać, iż wynika to ze stanu fizycznego pacjenta i progresji stanu zapalnego [22].

Umiarkowana i wysoka efektywność opieki personelu pielęgniarskiego w opinii chorych nie warunkowała ich ogólnej jakości życia. Można przypuszczać, iż pielęgniarki małą ilość czasu poświęcają na rozmowę z pacjentem, wykazują niski stopień empatii oraz skupiają się głównie na czynnościach instrumentalnych [23, 24]. 
Obecne badanie świadczy o wysokim i umiarkowanym poziomie opieki otrzymywanej przez pacjentów. Skłania to do przeprowadzenia bardziej szczegółowych analiz tego zagadnienia, co może zostać wykorzystane w opracowaniu jeszcze bardziej efektywnego programu pielęgnacji i leczenia. Niewątpliwie atutem niniejszych badań jest opracowanie autorskiego narzędzia badawczego, które może zostać wykorzystane w badaniach o podobnej tematyce i przyczynić się do zgromadzenia rzetelnych informacji dotyczących opieki sprawowanej przez pielęgniarki i opiekunów nieprofesjonalnych.

\section{Wnioski}

1. Chorzy na reumatoidalne zapalenie stawów ocenili poziom otrzymywanej opieki od opiekunów nieprofesjonalnych i pielęgniarek głównie jako wysoki i umiarkowany.

2. Jakość życia chorych na RZS w skalach: zaburzenia snu oraz energia oceniona została przez chorych jako niska, natomiast w skalach: reakcje emocjonalne i wyobcowanie społeczne jako wysoka.

3. Umiarkowany i wysoki poziom skuteczności otrzymywanej opieki od pielęgniarek nie wpływał na jakość życia chorych na RZS.

4. Wysoki poziom skuteczności otrzymywanej opieki od opiekunów nieprofesjonalnych warunkował wysoką jakość życia chorych na RZS w obszarze psychospołecznym.

\section{Piśmiennictwo}

1. Stanisławska-Biernat E, Sierakowska M, Sierakowski S. Nowe kryteria klasyfikacyjne reumatoidalnego zapalenia stawów. Reumatologia. 2010; 48(6): 361-365.

2. Głuszko P, Filipowicz-Sosnowska A, Tłustochowicz W. Reumatoidalne zapalenie stawów. Reumatologia. 2012; 50(2): 83-90.

3. Tłustochowicz W. Międzynarodowe wytyczne stosowania metotreksatu w chorobach reumatycznych, ze szczególnym uwzględnieniem reumatoidalnego zapalenia stawów. Reumatologia. 2012; 50(2): 91-92.

4. Zimmermann-Górska A (red.). Reumatologia kliniczna. Tom I. Warszawa: PZWL; 2008

5. Hersh A, von Scheven E, Yelin E. Adult outcomes of childhood-onset rheumatic diseases. Nat Rev Rheumatol. 2011; 7(5): 290-295

6. Sudoł K, Moskalewicz B. Długoterminowa opieka w przewlekłych chorobach reumatycznych - przejście od wieku młodzieńczego do opieki dla dorosłych. Reumatologia. 2008; 46(5): 290-294.

7. Wysocka-Skurska I, Sierakowska M, Sierakowski S. Ocena jakości życia pacjentów z reumatoidalnym zapaleniem stawów w zależności od stosowanej terapii farmakologicznej. Reumatologia. 2012; 50(1): 16-23.

8. Wrześniewski K. Badanie subiektywnego stanu zdrowia za pomocą polskiej adaptacji the Nottingham Heatlh Profile. W: Karski JB, Kirhner H, Leowski J (red.). Współczesne potrzeby i możliwości pomiaru zdrowia. Warszawa: Wyd. Ignis; 1997. 37-41.
9. Grygielska J. Ocena wybranych dziedzin życia w chorobach reumatycznych - analiza porównawcza badań ankietowych. Reumatologia. 2008; 46(4): 230-234.

10. Tasiemski T, Angiaszwili-Biedna N, Wilski M. Obiektywna i subiektywna ocena jakości życia osób z reumatoidalnym zapaleniem stawów - doniesienie wstępne. Ortop Traumatol Rehab. 2009; 11/4: 346-359.

11. Woynarowska B. Siedliskowe podejście w promocji zdrowia i jego realizacja w praktyce. W: Karski J (red.). Promocja zdrowia. Warszawa: Wyd. Ignis; 1999. 367-368.

12. Dzikowska M, Puto G. Pacjentka z reumatoidalnym zapaleniem stawów. W: Kózka M, Płaszewska-Żywko L (red.). Modele opieki nad chorym dorosłym. Warszawa: PZWL; 2010. 189-192.

13. Lenartowicz H, Kózka M. Metodologia badań w pielęgniarstwie. Podręcznik dla studiów medycznych. Warszawa: PZWL; 2011.

14. Kuryliszyn-Moskal A, Kaniewska K, Konarzewski P, Dzięcioł Z. Zaburzenia wydolności statycznej stóp u pacjentów z reumatoidalnym zapaleniem stawów - współczesne metody diagnostyki i terapii. Reumatologia. 2012; 50(6): 507-511.

15. Zimmermann-Górska I. Choroby reumatyczne. W: Szczeklik A, Gajewski P (red.). Choroby wewnętrzne. Kraków: Medycyna Praktyczna; 2009. 794-869.

16. Krzemińska-Dąbrowska I, Sudoł K, Moskalewicz B. Problemy zdrowia psychicznego chorych na reumatyzm. Reumatologia. 2007; 45(4): 215-218.

17. Paprocka-Borowicz M, Zawadzki M. Fizjoterapia w chorobach układu ruchu. Wrocław: Wyd. Med. Górnicki; 2007.

18. Baran M, Jaworek J. Wpływ terapii biologicznej na jakość życia chorych cierpiących na zapalne choroby reumatyczne - opinia pacjentów. W: Jaworek J, Gaździk T (red.). Fizjoterapia w profilaktyce chorób cywilizacyjnych i ich leczeniu. Kraków: Wyd. Uniwersytetu Jagiellońskiego; 2014.

19. Aletaha D et al. An American College of Rheumatology/European League Against Rheumatism Collaborative Initiative. Arthritis Rheum. 2010; 62: 2569-2581.

20. Samborski W. Niefarmakologiczne metody leczenia bólu w reumatologii. Przew Lek. 2007; 3: 55-59.

21. Houssien DA, Mckenna SP, Scott DL. The nottingham health profile as a measure of disease activity and outcome in rheumatoid arthritis. J Rheumatol. 1997; 36: 69-73.

22. Olewicz-Gawlik A, Hrycaj P. Jakość życia chorych na reumatoidalne zapalenie stawów - badania własne i przegląd literatury. Reumatologia. 2007; 45(6): 346-349.

23. Majda A, Zalewska-Puchała J. Postrzeganie opiekuńczości przez pielęgniarki. Mag Piel Położ. 2003; 11: 10-11.

24. Zalewska-Puchała J, Majda A, Górkiewicz M. Czy jesteśmy wystarczająco opiekuńcze. Mag Piel Położ. 2002; 2: 9-10.

Artykuł przyjęty do redakcji: 27.04.2016 Artykuł przyjęty do publikacji: 13.06.2016

Źródło finansowania: Praca nie jest finansowana z żadnego źródła. Konflikt interesów: Autorzy deklarują brak konfliktu interesów.
Adres do korespondencji:
Magdalena Staszkiewicz
ul. Pawła Włodkowica 3/50
31-452 Kraków
tel. kom.: 783874294
e-mail: baranmagdalenaa@gmail.com
Studentka studiów doktoranckich na Wydziale Nauk o Zdrowiu
Uniwersytet Jagielloński - Collegium Medicum w Krakowie 